\section{Field Performance of Tissue-cultured, Virus-tested 'Okinawan' Sweetpotato and Comparison with Some Promising Cultivars in Hawai'i}

\author{
Susan C. Miyasaka ${ }^{1,7,12}$, Sharon Motomura-Wages ${ }^{1,8}$, \\ Ishakh Pulakkatu-Thodi' ${ }^{2,9}$, Michael J. Melzer ${ }^{3,10}$, \\ Christopher A. Clark ${ }^{4,11}$, Don R. LaBonte ${ }^{5,11}$, and Arthur Q. Villordon ${ }^{6,11}$
}

AdDitional INDEX wORDs. Blosyrus asellus, Cylas formicarius elegantulus, Ipomoea batatas var. batatas, rough sweetpotato weevil, tissue culture

Summary. Tissue-cultured, virus-tested (TC) plantlets of sweetpotato (Ipomoea batatas var. batatas) cultivars Okinawan, LA 08-21p, and Murasaki-29 were obtained from Louisiana State University Agricultural Center. The objectives of field trials conducted at the Kula Agricultural Park, Maui, HI, were to compare yield and pest resistance of 1) 'Okinawan' obtained from a commercial (C) field with TC 'Okinawan' and 2) TC Okinawan with the aforementioned TC cultivars. Trials were planted Oct. 2015 and Aug. 2016 and harvested 5 months later. Storage roots were graded according to State of Hawai'i standards, and marketable yields included Grades AA, A, and B. In addition, injuries due to sweetpotato weevil (Cylas formicarius elegantulus) or rough sweetpotato weevil (Blosyrus asellus) were estimated. In both trials, fresh and dry weights of marketable storage roots of TC 'Okinawan' were nearly twice those from commercial planting material. In both trials, marketable fresh weights differed among the three TC cultivars; however, significant interactions were found, indicating that yields of cultivars differed between years. In the first field trial, 'LA 08-21 p' had fresh marketable yields 1.6 to 1.7 times greater than TC 'Okinawan' and Murasaki-29, respectively. In the second trial, fresh marketable yields of TC 'Okinawan' and 'LA 08-21p'were similar and 1.7 to 1.5 times greater than that of 'Murasaki-29', respectively. In both trials, 'LA 08-21p' had greater sweetpotato weevil injury than did the other two cultivars. Interestingly, in the second year, TC 'Okinawan' had greater rough sweetpotato weevil injury than did the other cultivars. Our results indicate that tissue-cultured planting materials increased marketable yields of TC 'Okinawan' compared with C 'Okinawan' sweetpotato and that the other TC cultivars did not produce greater yields than TC Okinawan.

S weetpotato production has increased dramatically in the state of Hawai'i from a farm gate value of $\$ 0.99$ million in 2002 to $\$ 7.3$ million in 2011 (Hawaii Department of Agriculture, 2013). The primary reason for the increased production was due to approval of a quarantine treatment to control insect pests, allowing export of sweetpotatoes out of the state. In 2011 , sweetpotatoes were grown on 1100 acres with an average yield of $15,200 \mathrm{lb} /$ acre. Most sweetpotato production is on the island of Hawai'i where the purple-fleshed cultivar Okinawan is grown and exported to the United States mainland.

There is an increased demand for sweetpotatoes by consumers in the United States, due to greater awareness of its healthful benefits (Wang et al., 2016). Purple-fleshed cultivars are rich in anthocyanins, which are popular dietary antioxidants (Teow et al., 2007). Cooked, purple-fleshed sweetpotatoes contain anthocyanins at $21.7 \mathrm{mg} / 100 \mathrm{~g}$ fresh weight and rank fourth in total anthocyanin levels among 20 fruit and vegetables consumed in Hawai'i (Franke et al., 2004). Antioxidants are thought to reduce the harmful effects of oxidative stress and to prevent development of chronic diseases (e.g., heart disease or cancer).

Sweetpotatoes are grown vegetatively from one cropping cycle to the next, and cultivar decline over time (reduced yields and quality) has been observed. For example, 'Centennial' has been grown since 1958 at the Sweet potato Research Station in Chase, LA, and its yield has decreased by $46 \%$ during a 35-year period (Villordon and LaBonte, 1995). This decline is thought to be due to an accumulation of viruses, other pathogens, and deleterious mutations (Clark et al., 2002).

In Hawai'i and elsewhere in the tropics, farmers obtain cuttings from extant plantings, and their "seed" stock has not been subjected to virus testing or any form of visual screening to eliminate off-types. This lack of virus-tested "seed" stock could lead to extreme off-grade shapes and sizes and inconsistencies in flesh color. Little is known about sweetpotato viruses present in Hawai'i. During 2013-14, 192 sweetpotato samples were collected on the islands of Kauai, Oahu, Molokai, Maui, and Hawai'i, and evaluations for 27 known sweetpotato viruses were made using polymerase chain reaction (PCR)-based detection assays. None of the targeted viruses were detected during this survey, either due to their absence in these samples or limitations of the detection assays employed (Melzer, 2014).

Another threat to the sustainability of sweetpotato production in Hawai'i is reduced root quality because of insect pests. The two major insect pests of sweetpotato in Hawai' $i$ are the sweetpotato weevil (Follett, 2006) and the rough sweetpotato weevil (Heu et al., 2014). The sweetpotato weevil is a major pest of sweetpotato worldwide, feeding and

\begin{tabular}{llll}
\hline $\begin{array}{l}\text { Units } \\
\text { To convert U.S. to SI, } \\
\text { multiply by }\end{array}$ & U.S. unit & SI unit & $\begin{array}{l}\text { To convert SI to U.S., } \\
\text { multiply by }\end{array}$ \\
\hline 0.4047 & acre $(\mathrm{s})$ & $\mathrm{ha}$ & 2.4711 \\
0.3048 & $\mathrm{ft}$ & $\mathrm{m}$ & 3.2808 \\
3.7854 & $\mathrm{gal}$ & $\mathrm{L}$ & 0.2642 \\
9.3540 & gal $/ \mathrm{acre}$ & $\mathrm{L} \cdot \mathrm{ha}^{-1}$ & 0.1069 \\
2.54 & inch $(\mathrm{es})$ & $\mathrm{cm}$ & 0.3937 \\
1.1209 & $\mathrm{lb} / \mathrm{acre}$ & $\mathrm{kg} \cdot \mathrm{ha}^{-1}$ & 0.8922 \\
28.3495 & $\mathrm{oz}$ & $\mathrm{g}$ & 0.0353 \\
62.5000 & $\mathrm{oz} / 100 \mathrm{lb}$ & $\mathrm{mg} / 100 \mathrm{~g}$ & 0.0160 \\
70.0532 & $\mathrm{oz} / \mathrm{acre}$ & $\mathrm{g} \cdot \mathrm{ha} \cdot{ }^{-1}$ & 0.0143 \\
1 & $\mathrm{ppm}$ & $\mu \mathrm{\mu g} \cdot \mathrm{g}^{-1}$ & 1 \\
$\left({ }^{\circ} \mathrm{F}-32\right) \div 1.8$ & ${ }^{\circ} \mathrm{F}$ & ${ }^{\circ} \mathrm{C}$ & $\left({ }^{\circ} \mathrm{C} \times 1.8\right)+32$ \\
& & &
\end{tabular}


multiplying within the storage root, resulting in inedible roots (Nottingham and Kays, 2002). The rough sweetpotato weevil is a new, invasive pest in Hawai' $i$, first detected on the island of Oahu in 2008, with subsequent detection on the island of Hawai'i in 2014 (Heu et al., 2014). This insect pest has not been found yet in the mainland United States. Grubs of rough sweetpotato weevil feed on storage root surfaces, severely damaging their appearances and reducing marketability.

The objectives of the field trials conducted at the Kula Agricultural

This project was funded by the County of Hawai' Department of Research and Development and by the USDA National Institute of Food and Agriculture Hatch project \#08029-H, managed by the University of Hawai'i at Manoa, College of Tropical Agriculture and Human Resources.

We thank Layne Matsushita at the Waiakea Research Station for acclimating and growing the virus-free, tissue-cultured plantlets in the greenhouse. We acknowledge the hard work of Pam Shingaki, Farm Manager, Maui Agricultural Research Center and Agricultural Technicians Edwin Perez, Glenn Otani, Earl Fujitani, Mark Kubo, Alfredo Hernandez, and Lanny Billings who installed, maintained, and harvested these field trials. Also, we thank Charles McCulloch at the University of California, San Francisco for his assistance with statistical analysis. Finally, we acknowledge the helpful suggestions for improving the manuscript from John $\mathrm{Hu}$ and Duane $\mathrm{P}$. Bartholomew, both from the University of Hawai'i, and Marisa Wall from U.S. Department of Agriculture Daniel K. Inouye Pacific Basin Agriculture Research Center.

Mention of a trademark, proprietary product, or vendor does not constitute a guarantee or warranty of the product by the University of Hawai'i or Louisiana State University and does not imply its approval to the exclusion of other products or vendors that also might be suitable.

${ }^{1}$ Department of Tropical Plant and Soil Sciences, University of Hawai'i at Manoa, Komohana Agriculture Research and Extension Center, 875 Komohana Street, Hilo, HI 96720

${ }^{2}$ Department of Plant and Environmental Protection Sciences, University of Hawai'i at Manoa, Komohana Agriculture Research and Extension Center, 875 Komohana Street, Hilo, HI 96720

${ }^{3}$ Department of Plant and Environmental Protection Sciences, University of Hawai'i at Manoa, 3190 Maile Way, Honolulu, HI 96822

${ }^{4}$ Department of Plant Pathology and Crop Physiology, Louisiana State University AgCenter, Baton Rouge, LA 70803

${ }^{5}$ School of Plant, Environmental, and Soil Sciences, Louisiana State University AgCenter, Baton Rouge, LA 70803

${ }^{6}$ Louisiana State University AgCenter, Sweet Potato Research Station, Chase, LA 71324

${ }^{7}$ Professor of Agronomy

${ }^{8}$ Assistant Extension Agent

${ }^{9}$ Junior Researcher

${ }^{10}$ Assistant Researcher

${ }^{11}$ Professor

${ }^{12}$ Corresponding author. E-mail: miyasaka@hawaii. edu.

https://doi.org/10.21273/HORTTECH04009-18
Park on the island of Maui were to compare yield and pest resistance of 1) 'Okinawan' obtained from a C field with TC 'Okinawan' and 2) TC sweetpotato cultivars Okinawan, LA 08-2lp, and Murasaki-29.

\section{Materials and methods}

Planting materials. TC sweetpotato cultivars were obtained from the Louisiana State University Agricultural Center (LSU AgCenter): TC Okinawan, LA 08-2lp, and Murasaki-29. LSU AgCenter received the TC 'Okinawan' from a commercial nursery on the U.S. mainland, and it tested free of viruses without the need for therapy. C 'Okinawan' was obtained from a farmer's field in Pepeekeo, HI. Both TC and C 'Okinawan' were similar in morphological and agronomic traits (e.g., shape of leaves and appearance and taste of storage roots).

The LSU AgCenter sweetpotato cultivar LA 08-2 $\mathrm{lp}$ is an advanced line with total yield at $80 \%$ of commercial cultivar Beauregard in multiple replicated yield trials. It is resistant to southern root-knot nematode (Meloidogyne incognita) and is susceptible to intermediate resistance to soil rot caused by Streptomyces ipomoeae. In addition, it has resistances to java black rot (Diplodia gossypina), bacterial root rot (Erwinia chrysanthemi), fusarium root rot (Fusarium solani), rhizopus soft rot (Rhizopus sp.), and fusarium wilt (Fusarium oxysporum f.sp. batatas). This line has purple flesh, red skin, and a creamy texture and mild starchy flavor when baked.

'Murasaki-29' is another promising sweetpotato cultivar (LaBonte et al., 2008) that has white flesh, a dark purple skin, and broad-spectrum disease resistance, as well as resistance to the southern root-knot nematode. Neither cultivar has been grown and evaluated previously in Hawai'i.

TC cultivars were acclimated from plantlets and multiplied in pots in the greenhouse at the Waiakea Research Station in Hilo, HI (lat. $19.6444^{\circ} \mathrm{N}$, long. $155.08027^{\circ} \mathrm{W}$, elevation $400 \mathrm{ft}$ ). Cuttings were obtained from nursery-grown plants and planted in the field at the Maui Agricultural Research Center in Kula, HI (lat. $20.7564^{\circ} \mathrm{N}$, long. $156.3289^{\circ} \mathrm{W}$, elevation $3100 \mathrm{ft}$ ). Cuttings were taken from these field-grown plants and planted in the first trial at the Kula Agricultural Park (lat. $20.7928^{\circ} \mathrm{N}$, long. $156.3540^{\circ} \mathrm{W}$, elevation $1400 \mathrm{ft}$ ). Cuttings were taken from this first trial and grown in the field at the Maui Agricultural Research Center. Then, cuttings were taken from the Maui Agricultural Research Center for the second trial.

Kula Agricultural Park. Two sweetpotato trials were conducted at the Kula Agricultural Park on the island of Maui. The soil series at the Kula Agricultural Park is a Keahua silty clay loam (fine, kaolinitic, isohyperthermic, ustic haplocambid).

Before each planting date, eight soil subsamples were taken between 6 and 10 inches depth from each plot, composited, and a representative soil sample sent to the University of Hawai'i's Agricultural Diagnostic Service Center for analysis of $\mathrm{pH}$, phosphorus $(\mathrm{P})$, potassium $(\mathrm{K}), \mathrm{cal}-$ cium $(\mathrm{Ca})$, and magnesium $(\mathrm{Mg})$. Soil $\mathrm{pH}$ was measured using the saturated paste method; $\mathrm{P}$ was extracted using the modified Truog method; and soil cations $(\mathrm{K}, \mathrm{Ca}$, and $\mathrm{Mg}$ ) were extracted with ammonium acetate (1 M, pH 7.0) (Hue et al., 2000). Nutrients were determined using inductively coupled plasma emission spectroscopy (Optima 7000DV spectrometer; PerkinElmer, Waltham, MA). Results were used to determine liming and fertilizer applications.

Results of soil analyses are as follows (before trials 1 and 2 , respectively): 5.9 and $6.1 \mathrm{pH}, 462$ and $726 \mathrm{ppm} \mathrm{P}$, 884 and 980 ppm K, 1790 and 2581 ppm Ca, and 334 and 481 ppm Mg. Soil from the Kula Agricultural Park is a volcanic ash soil and categorized as a light soil. Soil $\mathrm{pH}$ was considered to be sufficient; extractable P was considered to be very high; extractable $\mathrm{K}$ was considered to be high; and extractable $\mathrm{Ca}$ and $\mathrm{Mg}$ were considered to be low (Yost and Uchida, 2000).

EXPERIMENTAL METHODS COMMON TO BOTH FIELD TRIALS. Treatments were C 'Okinawan', TC 'Okinawan', TC 'LA 08-2lp', and TC 'Murasaki-29' with four replicates arranged in a randomized complete block design. Each block included one 30-ft row of TC 'Okinawan', TC 'LA 08-2lp', and TC 'Murasaki29 ' and three 30 -ft rows of C 'Okinawan'. Cuttings were spaced $\mathrm{l} \mathrm{ft}$ apart in the row and each row was spaced $5 \mathrm{ft}$ apart.

It was hypothesized that C 'Okinawan' sweetpotatoes contained 
viruses. To reduce the spread of viruses by insect vectors, cover crops were planted in a 5 - $\mathrm{ft}$ row between the TC plots and C 'Okinawan' plots. Cover crops consisted of two rows of 'Sordan 79' sorghum-sudangrass (Sorghum bicolor nothosp. drummondii) that were planted $1 \mathrm{ft}$ apart. Also, one row of 'Orangeade' marigold (Tagetes erecta) was planted next to the sorghumsudangrass at a spacing of $1 \mathrm{ft}$ apart to retard movement of nematodes and other soil-borne pests between TC plots and C 'Okinawan' plots.

Sweetpotatoes were irrigated daily at $1 \mathrm{gal} /$ plant per day, using drip irrigation lines with holes spaced $\mathrm{l} \mathrm{ft}$ apart $[0.9 \mathrm{gal} / \mathrm{h}($ XFD0912500XF; Rainbird Corp., Tucson, AZ)]. Soluble fertilizer was applied through the drip irrigation system (further details are provided later under each trial). Irrigation was stopped $\approx 1$ week before harvest.

Storage roots were harvested after $\approx 5$ months of growth. Storage roots of sweetpotatoes were graded according to the Hawaii Department of Agriculture (1974) standards (AA, A, B, and off-grades). Grade AA storage roots had diameters between 1.75 and 3.25 inches, lengths between 3 and 9 inches, and fresh weights not more than $16 \mathrm{oz}$. Grade A storage roots had diameters between 1.75 and 3.75 inches, lengths between 3 and 10 inches, and fresh weights not more than $24 \mathrm{oz}$. Grade $\mathrm{B}$ storage roots had diameters not less than 1.75 inches and fresh weights not more than $32 \mathrm{oz}$. Off-grade storage roots had diameters less than 1.75 inches or fresh weights more than 32 oz. Then, roots were placed into subcategories based on no injury, or injuries due to sweetpotato weevil, rough sweetpotato weevil, mechani$\mathrm{cal}$, or other (including nematodes, birds, etc.). Fresh weights were determined. In each treatment, two representative storage roots from each grade were cut into slices, fresh weights taken, dried at $60{ }^{\circ} \mathrm{C}$ to constant weight, and reweighed. The marketable category combined $\mathrm{AA}, \mathrm{A}$, and $\mathrm{B}$ grades.

Trial 1. In the first trial, sweetpotato cuttings were planted into four blocks on 22 Oct. 2015. On 19 Oct. 2015, sorghum $\times$ sudangrass seedlings were planted, and marigolds were planted on 21 Oct. 2015. On 6 Nov. 2015, $23.8 \mathrm{lb} /$ acre nitrogen
(N) was applied with fertilizer (20N-8.7P-16.6K). On 7 Dec. 2015 and 14 Jan. 2016, $29.5 \mathrm{lb} /$ acre $\mathrm{N}$ was applied at each date using $\mathrm{Ca}$ nitrate. No herbicides were applied; instead, the plots were hand-weeded. No pesticides were applied. Storage roots were harvested during 23 to 28 Mar. 2016 after $\approx 5$ months of growth.

Trial 2. On 29 to 30 Aug. 2016, sweetpotato cuttings were planted into four blocks. On 16 Aug. 2016, sorghum-sudangrass was planted and marigolds were planted on 12 Oct. 2016. On 24 Aug. 2016, pre-emergent herbicide flumioxazin (Chateau ${ }^{\circledR}$ SW; Valent Agricultural Products, Walnut Creek, CA) was sprayed at $1 \mathrm{oz} /$ acre a.i. On $16 \mathrm{Sept}$. $2016,23.8 \mathrm{lb} /$ acre of $\mathrm{N}$ was applied with fertilizer $(20 \mathrm{~N}-8.7 \mathrm{P}-16.6 \mathrm{~K})$. On 14 Oct. 2016 and 11 Nov. 2016, $29.5 \mathrm{lb} /$ acre of $\mathrm{N}$ was applied at each date using Ca nitrate. On 18 Nov. 2016 and 13 Dec. 2016, K [0N-0P-18.3K (K-Mag; Mosaic Co., Plymouth, MN)] was applied at $31 \mathrm{lb} /$ acre of $\mathrm{K}$ at each date. On 1 to 3 Feb. 2017, plots were harvested after $\approx 5$ months of growth.

As the result of build-up of pest populations, pesticides were applied as follows: Streptomyces lydicus (Actinovate ${ }^{\circledR}$ AG; Novozymes BioAg, Milwaukee, WI) was injected into the irrigation system at $0.024 \mathrm{~kg} \cdot \mathrm{ha}^{-1}$ a.i. to control potential, fungal disease problems. Carbaryl $\left(\right.$ Sevin $^{\circledR}$ XLR Plus; Bayer CropScience, Research Triangle, NC) was applied to control sweetpotato weevil and rough sweetpotato weevil at $0.28 \mathrm{~L} \cdot \mathrm{ha}^{-1}$ a.i. on 30 Aug. 2016, $0.56 \mathrm{~L} \cdot \mathrm{ha}^{-1}$ a.i. on $7 \mathrm{Oct}$. 2016 , and $0.85 \mathrm{~L} \cdot \mathrm{ha}^{-1}$ a.i. on $15 \mathrm{Nov}$. 2016. Spiromesifen (Oberon ${ }^{\circledR} 2 \mathrm{SC}$, Bayer CropScience) was applied to control mites at $0.15 \mathrm{~L} \cdot \mathrm{ha}^{-1}$ a.i. on 1 Nov. 2016. Imidacloprid (Pasada 1.6F; Makhteshim Agan of North America, Raleigh, NC) was applied at $0.038 \mathrm{~L} \cdot \mathrm{ha}^{-1}$ a.i. on 15 Nov. 2016 and $0.045 \mathrm{~L} \cdot \mathrm{ha}^{-1}$ a.i. on 23 Dec. 2016 to control sweetpotato weevil. Spinosad (Success; Dow AgroSciences, Indianapolis, IN) was applied at $0.10 \mathrm{~L} \cdot \mathrm{ha}^{-1}$ a.i. on 21 Nov. 2016 to control sweetpotato vine borer (Omphisa anastomosalis). Spinetoram (Radiant $^{\circledR}$, Dow AgroSciences) was applied at $0.0037 \mathrm{~L} \cdot \mathrm{ha}^{-1}$ a.i. on 23 Dec. 2016 and on 13 Jan. 2017 to control sweetpotato vine borer.
Statistical analysis. Data were separated into two files: 1) TC 'Okinawan' vs. C 'Okinawan' and 2) comparison of three TC cultivars. Analyses of variance were conducted using PROC MIXED (SAS version 9.4; SAS Institute, Cary, NC). Means of fresh weights by category of cultivars within a cropping season were compared using a pairwise $t$ test of least-square means with a Bonferroni comparisons correction (Dunn, 1961).

VIRUS INDEXING. Grafting of sweetpotato vines onto brazilian morningglory [BMG (Ipomoea setosa)] seedlings is a commonly used method to multiply viruses to detectable levels and/ or observable, recognizable symptoms (Clark et al., 2013). Sweetpotato cuttings were planted in pots in the nursery following the last field harvest. On 24 Apr. 2017, five vines from each treatment and cultivar were wedgegrafted onto BMG seedlings and grown for $\approx 2$ months. Leaves from BMG for each treatment were sampled on 27 June 2017 and sent for virus indexing.

Total nucleic acids (TNAs) were extracted from grafted BMG following the method of $\mathrm{Li}$ et al. (2008). TNA from ungrafted BMG seedlings served as a negative control for virus indexing. Plant TNAs were tested by reverse transcriptase (RT) PCR for potyviruses using the universal potyvirus primers $\mathrm{CI}-\mathrm{F}$ and $\mathrm{CI}-\mathrm{R}$ (Ha et al., 2008) and the multiplex assay targeting Sweet potato feathery mottle virus (SPFMV), Sweet potato virus $C$ (SPVC), Sweet potato virus G(SPVG), and Sweet potato virus 2 (SPV2) developed by $\mathrm{Li}$ et al. (2012). Assays were performed using SuperScript III One-Step RT-PCR with Platinum Taq DNA Polymerase (Thermo Fisher Scientific, Waltham, MA). Primers PNad5f (5'-GATGCTTCTTGGGGCTTCTTKT-3') and PNad5mr (5' -ATCTCCAGTCACCAACATTRGCATAA-3') targeting the nicotinamide adenine dinucleotide dehydrogenase subunit $\mathbf{5}$ served as an internal positive control for the assays. In addition, BMG tissue was tested for the presence of potyviruses using a universal potyvirus lateral flow assay (Agdia, Elkhart, IN).

Plant TNAs were tested by PCR for geminiviruses using primers SPGI and SPG2 (Li et al. 2004) using GoTaq $^{\circledR}$ Green Master Mix (2X) (Promega, Madison, WI). Primers 
MDH-H968 and MDH-Cl163 (Li et al., 2004) served as an internal positive control for the assay. The positive control both for the potyvirus and geminivirus assays was sweetpotato tissue infected with SPFMV, SPVC, SPVG, SPV2, Sweet potato leaf curl virus (SPLCV), and Sweet potato symptomless virus 1 .

\section{Results}

TC PLANTING MATERIALS. TC 'Okinawan' sweetpotato had greater fresh weight yields in categories AA $(P=0.01), \mathrm{A}(P=0.03), \mathrm{B}(P=0.02)$, marketable [sum of categories AA, A, and $\mathrm{B}(P=0.01)]$, off-grade $(P=$ 0.02 ), and total [sum of marketable and off-grade $(P=0.008)]$ compared with those from commercial planting materials (Fig. 1). No differences due to cropping season were found. Similar results were found for dry weight yields with the exception of an interaction found between planting materials and year for storage roots in AA category (Table 1). Marketable fresh and dry weight yields of TC 'Okinawan' were almost twice those of $\mathrm{C}$ 'Okinawan'.

Cultivar comparison. Marketable fresh weight yields of cultivars when averaged across both years differed $(P=0.024)$; however, there was a significant cultivar by year interaction $[P=0.007$ (Fig. 2)]. For example, in 2015, 'LA 08-21p' had the highest fresh weight marketable yield compared with the other two cultivars, whereas in 2016, fresh weight marketable yield of 'LA 08-2lp' did not differ from the other two cultivars. Similar interaction effects between cultivar and year were found for marketable dry weight yield ( $\mathrm{Ta}-$ ble 2).

Significant differences were found between years for off-grade fresh weight yields averaged across cultivars $[P=0.014$ (Fig. 2) $]$; there was no significant interaction found between cultivar and year $(P=0.051)$. In the year 2015 (cropping season 2015-16), off-grade fresh weight yield was $11,582 \mathrm{~kg} \cdot \mathrm{ha}^{-1}$ compared with $567 \mathrm{l} \mathrm{kg} \cdot \mathrm{ha}^{-1}$ in the year 2016 (cropping season 2016-17). Similar results were found for off-grade dry weight yields (Table 2). In the year 2015 , growth of storage roots was greater, resulting in too-large storage roots that exceeded the maximum weight and dimensions of marketable roots. Cultivars differed in fresh weight of off-grade storage roots when averaged across 2 years $(P$ $=0.035)$, with 'LA 08-2lp' having the greatest fresh weight and 'Murasaki-29' having the lowest fresh weight (Fig. 2). Cultivars differed for dry weight of off-grade storage roots when averaged across 2 years, with 'Murasaki-29' having the lowest dry weight (Table 2).

Cultivars differed in total fresh weight yield of storage roots averaged across both years $(P=0.005)$; however, a significant interaction was found between year and cultivar $[P=$ 0.02 (Fig. 2)], indicating that total yields of cultivars differed between years. For example, 'LA 08-2lp' had the greatest total fresh weight yields in the year 2015; however, it did not differ from TC 'Okinawan' in the year 2016. Total dry weight yield of storage roots averaged across both years differed among cultivars; no significant interaction was found between year and cultivar (Table 2). 'Murasaki-29' had the lowest total dry weight yield compared with the other two cultivars.

Cultivars differed in incidence of sweetpotato weevil injury in marketable storage roots averaged across both years; no significant interaction was found between year and cultivar (Table 2). 'LA 08-2lp' had the greatest injury due to sweetpotato weevil compared with the other two cultivars.

Cultivars also differed in incidence of rough sweetpotato weevil injury in marketable storage roots averaged across both years; however, an interaction was found between cultivar and year (Table 2). Little injury due to rough sweetpotato weevil was found in all cultivars during the year 2015, whereas in the year 2016, TC 'Okinawan' had dramatically greater injury due to rough sweetpotato weevil relative to the other two cultivars.

VIRUS INDEXING. RT-PCR and serological indexing for potyviruses and PCR indexing for geminiviruses were negative for the targeted viruses. The methodology appeared to be sound, because virus-infected sweetpotato tissue used as positive controls for the assays produced amplification products of the expected size for both primers targeting virus sequences and the internal control target genes.

\section{Discussion}

TC PLANTING MATERIALS. Marketable fresh and dry weight yields of TC 'Okinawan' sweetpotatoes were almost twice those of C 'Okinawan.' Initially, it was hypothesized that $\mathrm{C}$ 'Okinawan' planting materials contained viruses; however, no evidence of viruses were found using RT-PCR or PCR indexing. It is possible that viruses were present in C 'Okinawan' planting materials, although at too low a concentration to be detected using these methods, and that these viruses reduced yields. It is well known that viruses (e.g., SPFMV, SPLCV, and combinations of viruses SPFMV and SPVG, or SPFMV, SPVG, and SPV2), reduce marketable yields of sweetpotatoes in the mainland United States by $10 \%$ to $80 \%$, depending on the cultivar and/or environment (Bryan et al., 2003; Carroll et al., 2004; Clark and Hoy, 2006; Ling et al., 2010).

Another possibility is that uncharacterized systemic pathogens exist, since sweetpotato is host to more than 30 known virus species (Clark et al., 2012). Advanced diagnostic technologies such as highthroughput sequencing ( $\mathrm{Gu}$ et al., 2014; Kreuze et al., 2009) may be used in the future to determine whether undetected pathogens exist in Hawaiian sweetpotato, resulting in reduced yields observed in this study.

Alternatively, it is possible that the individual plant of 'Okinawan' sweetpotato placed into tissue-culture was a high-yielding, superior line compared with commercial planting materials found in Hawai'i. In previous research, differences within a sweetpotato cultivar (i.e., Jewel) were found using randomly amplified polymorphic DNA markers, probably as a result of mutations during vegetative propagation from adventitious roots (Villordon and LaBonte, 1995). Although both 'Okinawan' lines appeared identical based on morphological and agronomic traits, it is possible that genetic differences existed between the two lines.

There is a need to determine which viruses (if any) are present in Hawai'i before a TC "seed" program is pursued. Although previous efforts to detect viruses in Hawaiian sweetpotato were unsuccessful 
(Melzer, 2014), more recent efforts using improved detection assays indicate some potyviruses may infect Hawai'i's sweetpotato (A. de Silva and M.J. Melzer, unpublished data).

COMPARISON OF TISSUECULTURED CULTIVARS. 'LA 08-21p'

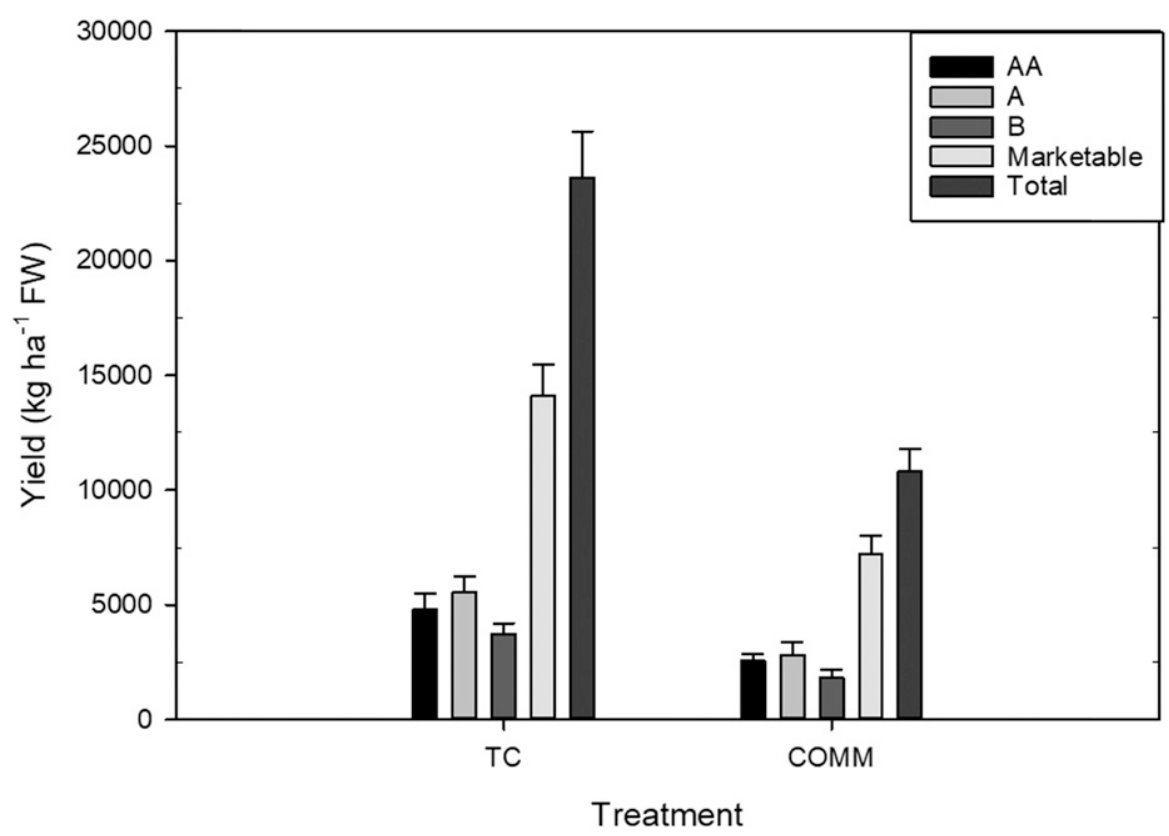

Fig. 1. Fresh weight yield of storage roots of 'Okinawan' sweetpotato grown from tissue-cultured, virus-tested (TC) planting materials and those grown from commercial cuttings (COMM) averaged across two cropping seasons. Marketable fresh weight yields are the sum of categories AA, A, and B (Hawaii Department of Agriculture, 1974). Total yields are the sum of fresh weight yields of marketable and off-grade. Grade AA storage roots had diameters between 1.75 and 3.25 inches, lengths between 3 and 9 inches, and fresh weights not more than $16 \mathrm{oz}$. Grade A storage roots had diameters between 1.75 and 3.75 inches, lengths between 3 and 10 inches, and fresh weights not more than $24 \mathrm{oz}$. Grade B storage roots had diameters not less than 1.75 inches, and fresh weights not more than $32 \mathrm{oz}$. Off-grade storage roots had diameters less than 1.75 inches, or fresh weights more than $32 \mathrm{oz}$. Error bars are SE. $1 \mathrm{inch}=$ $2.54 \mathrm{~cm}, 1 \mathrm{oz}=28.3495 \mathrm{~g}, 1 \mathrm{~kg} \cdot \mathrm{ha}^{-1}=0.8922 \mathrm{lb} /$ acre . had the greatest marketable fresh weight yield of $20,297 \mathrm{~kg} \cdot \mathrm{ha}^{-1}$ in the year 2015; however, TC 'Okinawan' had the greatest marketable fresh weight yield of $16,408 \mathrm{~kg} \cdot \mathrm{ha}^{-1}$ in the year 2016 (Fig. 2). Environmental conditions (e.g., winter season vs. fall season), build-up of pest populations during second cropping cycle, and/or management practices (e.g., fertilization practices, pesticide applications) obviously affected growth and yield of cultivars between the 2 years. These marketable yields are similar to the average yield of $20,500 \mathrm{~kg} \cdot \mathrm{ha}^{-1}$ reported for sweetpotato during 2004 to 2008 in the United States (Ling et al., 2010).

Although 'LA 08-21p' has the potential for greater fresh weight yield of storage roots, it was also more vulnerable to sweetpotato weevil, with damage of $24 \%$ among marketable storage roots averaged across 2 years (Table 2 ). This injury due to sweetpotato weevil was greater on 'LA 08-2 lp' than TC 'Okinawan' or 'Murasaki-29', both of which appear to have some resistance to this insect pest. According to Jackson and Harrison (2013), 'Murasaki29' appeared to be especially resistant to sweetpotato weevil at Charleston, SC, under relatively low insect pressure.

It is hypothesized that the greater susceptibility of 'LA 08 21 p' to sweetpotato weevil is due to its growth habit of forming tight clusters of storage roots close to the

Table 1. Comparison of DW yields of storage roots in 'Okinawan' sweetpotato from two sources of planting materials: TC and $\mathrm{C}$ grown over two cropping seasons and replicated four times (Block) at the Kula Agricultural Park on the island of Maui in Hawai'i. Marketable fresh weight yields are the sum of categories AA, A, and B (Hawaii Department of Agriculture, 1974). Total yields are the sum of fresh weight yields of marketable and off-grade. Grade AA storage roots had diameters between 1.75 and 3.25 inches, lengths between 3 and 9 inches, and fresh weights not more than 16 oz. Grade A storage roots had diameters between 1.75 and 3.75 inches, lengths between 3 and 10 inches, and fresh weights not more than 24 oz. Grade B storage roots had diameters not less than 1.75 inches and fresh weights not more than 32 oz. Off-grade storage roots had diameters less than 1.75 inches or fresh weights more than $32 \mathrm{oz}^{\mathrm{z}}$

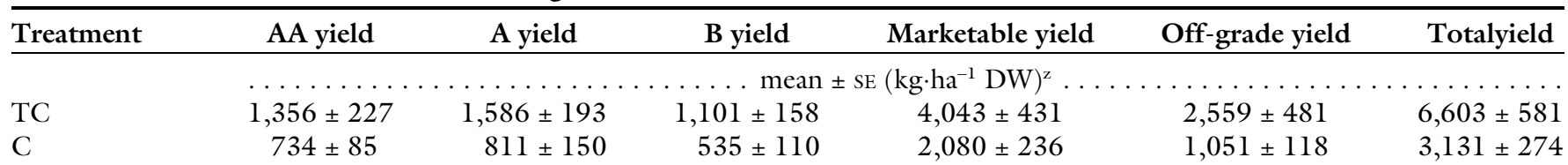

\begin{tabular}{|c|c|c|c|c|c|c|}
\hline \multicolumn{7}{|c|}{$P>\mathrm{F}$} \\
\hline Year $(Y)$ & 0.110 & 0.43 & 0.390 & 0.100 & 0.09 & 0.970 \\
\hline Block & 0.520 & 0.64 & 0.530 & 0.450 & 0.35 & 0.550 \\
\hline Treatment $(\mathrm{T})$ & 0.014 & 0.02 & 0.045 & 0.015 & 0.02 & 0.008 \\
\hline
\end{tabular}

${ }^{\mathrm{z}} \mathrm{l}$ inch $=2.54 \mathrm{~cm}, \mathrm{l} \mathrm{oz}=28.3495 \mathrm{~g}, \mathrm{l} \mathrm{kg} \cdot \mathrm{ha}^{-1}=0.8922 \mathrm{lb} /$ acre .

$\mathrm{DW}=$ dry weight; $\mathrm{TC}=$ tissue-cultured, virus-tested; $\mathrm{C}=$ commercial. 


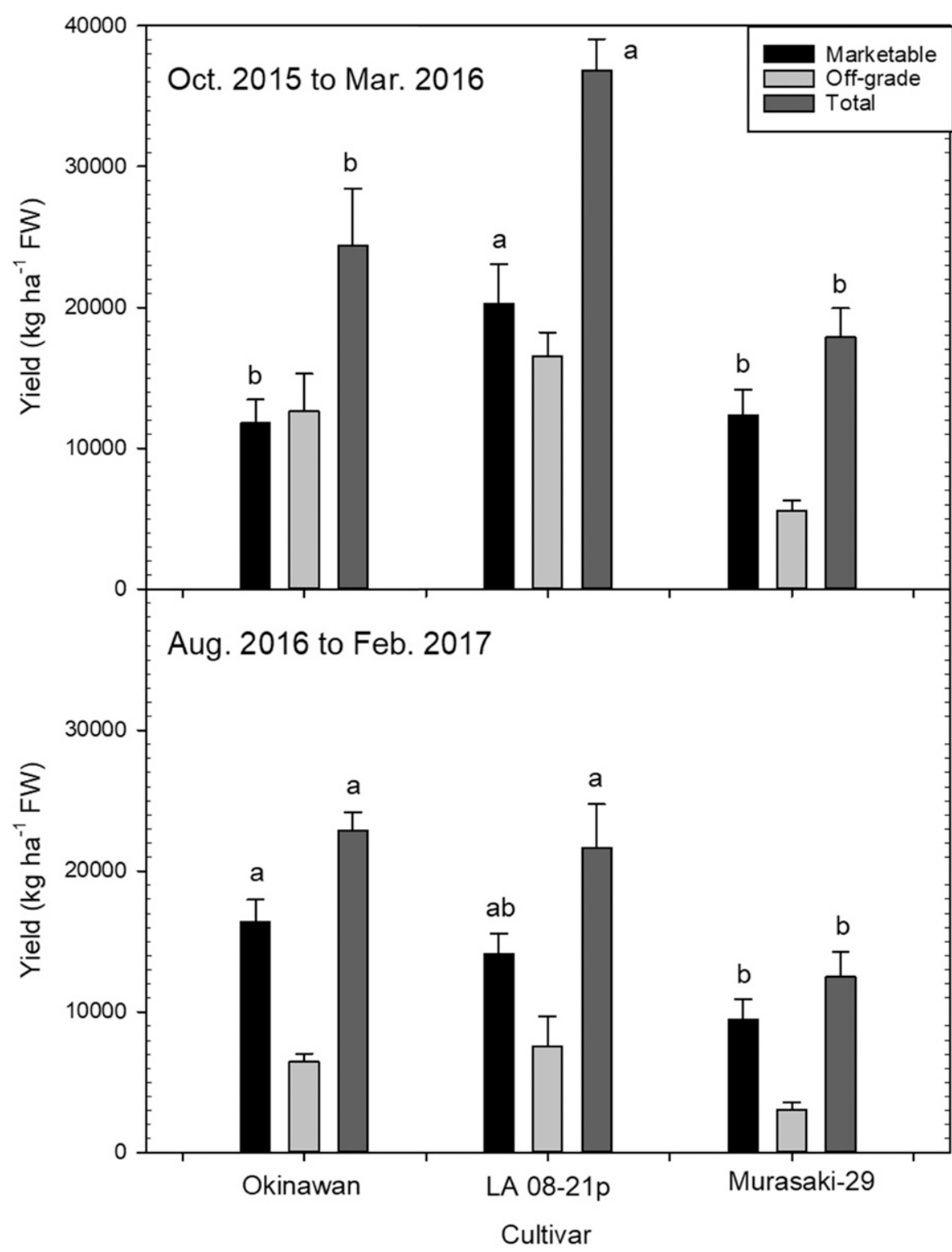

Fig. 2. Fresh weight yield of storage roots of tissue-cultured, virus-tested (TC)

'Okinawan', 'LA 08-21p', and 'Murasaki-29' sweetpotato grown during the year 2015 (cropping season 2015-16) and the year 2016 (cropping season 2016-17) at the Kula Agricultural Park on the island of Maui in Hawai'i. Marketable fresh weight yields are the sum of categories AA, A, and B (Hawaii Department of Agriculture, 1974). Total yields are the sum of fresh weight yields of marketable and off-grade. Grade AA storage roots had diameters between 1.75 and 3.25 inches, lengths between 3 and 9 inches, and fresh weights not more than $16 \mathrm{oz}$. Grade A storage roots had diameters between 1.75 and 3.75 inches, lengths between 3 and 10 inches, and fresh weights not more than 24 oz. Grade B storage roots had diameters not less than 1.75 inches, and fresh weights not more than $32 \mathrm{oz}$. Off-grade storage roots had diameters less than 1.75 inches, or fresh weights more than $32 \mathrm{oz}$. Error bars are SE. Means of fresh weights by category of cultivars within a cropping season were compared using a pairwise $t$ test of least square means with a Bonferroni comparisons correction $[P<0.017$ (Dunn, 1961)]; 1 inch = $2.54 \mathrm{~cm}, 1 \mathrm{oz}=28.3495 \mathrm{~g}, 1 \mathrm{~kg} \cdot \mathrm{ha}^{-1}=0.8922 \mathrm{lb} /$ acre .

soil surface (Fig. 3). According to Hahn and Leuschner (1982), sweetpotato weevils cannot mine through soil to reach storage roots deep underground, and they normally attack only the upper parts of storage roots exposed by soil cracking. Similarly,
Stathers et al. (2003) found a negative correlation between resistance of cultivars to african sweetpotato weevil (Cylas puncticollis) and the distance from the soil surface to the top of the storage root at Serere, Tanzania.
Before 2015, sweetpotatoes had not been planted at the Kula Agricultural Park for many years, and low damage due to rough sweetpotato weevil was observed during that first planting. It is important to note that no pesticides were applied during the year 2015 , whereas in the year 2016, various pesticides were applied against major pests. Injury from rough sweetpotato weevil was relatively low in all three cultivars during the first growing season, but the injury was considerably higher (37\%) during the year 2016 in TC 'Okinawan', despite the application of pesticides (Table 2). It is likely that the population of rough sweetpotato weevils built up and increased injury of TC 'Okinawan'. 'LA 08-2lp' was not particularly susceptible to rough sweetpotato weevil during the second season despite the formation of roots close to the surface and 'Murasaki-29' in general fared well against both weevils. The differences in defense mechanism among these cultivars against these weevils will require further investigation.

Understanding mechanisms of host plant resistance in sweetpotato is still evolving. Some early studies have suggested that a combination of nonpreference (antixenosis) and escape resistance (roots being inaccessible) could exist in some cultivars against sweetpotato weevil (Barlow and Rolston, 1981). Other types of resistance mechanisms (antibiosis or tolerance) have been reported by various researchers in different sweetpotato cultivars (Mao et al., 2001). Active resistance against african sweetpotato weevil has been identified in one African landrace and the chemical properties of its latex have largely supported this resistance mechanism (Stevenson et al., 2009). It appears that 'Murasaki-29' could have an active resistance mechanism against weevil species, because previous studies have shown resistance to oviposition and reduced reproduction of sweetpotato weevil (J. Chen, personal communication). In our studies, 'Murasaki-29' consistently performed better against both weevils based on lower incidence of weevil damage. Further studies are needed to fully understand the resistance mechanism against weevils among these cultivars. 
Table 2. Comparison of DW yields of storage roots, incidence of sweetpotato weevil (\%) in marketable storage roots, and incidence of rough sweetpotato weevil in marketable storage roots of three treatments (TC 'Okinawan',

'LA 08-21p', 'Murasaki-29') grown over two cropping seasons (year) and replicated four times (Block) at the Kula Agricultural Park on the island of Maui in Hawai'i. Marketable DW yields are the sum of categories AA, A, and B (Hawaii Department of Agriculture, 1974). Total yields are the sum of dry weight yields of marketable and off-grade. Grade AA storage roots had diameters between 1.75 and 3.25 inches, lengths between 3 and 9 inches, and fresh weights not more than $16 \mathrm{oz}$. Grade A storage roots had diameters between 1.75 and 3.75 inches, lengths between 3 and 10 inches, and fresh weights not more than $24 \mathrm{oz}$. Grade B storage roots had diameters not less than 1.75 inches and fresh weights not more than $32 \mathrm{oz}$. Off-grade storage roots had diameters less than 1.75 inches or fresh weights more than $32 \mathrm{oz}^{\mathrm{z}}$

\begin{tabular}{|c|c|c|c|c|c|}
\hline Treatment & $\begin{array}{c}\text { Marketable yield } \\
\left(\mathrm{kg} \cdot \mathrm{ha}^{-1} \mathrm{DW}\right)^{\mathrm{z}}\end{array}$ & $\begin{array}{c}\text { Off-grade yield } \\
\left(\mathrm{kg} \cdot \mathrm{ha}^{-1} \mathrm{DW}\right)\end{array}$ & $\begin{array}{c}\text { Total yield } \\
\left(\mathrm{kg} \cdot \mathrm{ha} \mathrm{a}^{-1} \mathrm{DW}\right)\end{array}$ & $\begin{array}{c}\text { Marketable (\% } \\
\text { sweetpotato weevil) }\end{array}$ & $\begin{array}{l}\text { Marketable (\% rough } \\
\text { sweetpotato weevil) }\end{array}$ \\
\hline & & & mean $\pm s$ & & \\
\hline 2015 & $4,026 \pm 408$ & $2,899 \pm 381$ & $6,915 \pm 650$ & $13.7 \pm 4.7$ & $3.0 \pm 1.1$ \\
\hline TC Okinawan & $4,043 \pm 431$ & $2,559 \pm 481 \mathrm{a}^{\mathrm{y}}$ & $6,603 \pm 581 \mathrm{a}$ & $3.2 \pm 1.3 b$ & $20.4 \pm 8.0$ \\
\hline LA 08-2lp & $4,433 \pm 522$ & $2,867 \pm 430 a$ & $7,300 \pm 808 a$ & $24.3 \pm 5.3 \mathrm{a}$ & $4.4 \pm 1.2$ \\
\hline TC Okinawan & $3,295 \pm 476 b$ & $3,400 \pm 759$ & $6,694 \pm 1,136$ & $5.5 \pm 2.0$ & $3.6 \pm 1.2 \mathrm{a}$ \\
\hline LA $08-21 p$ & $5,154 \pm 858 a$ & $3,756 \pm 155$ & $8,910 \pm 812$ & $31.2 \pm 9.0$ & $3.7 \pm 2.5 \mathrm{a}$ \\
\hline Murasaki & $3,628 \pm 468 \mathrm{ab}$ & $1,513 \pm 176$ & $5,141 \pm 557$ & $4.3 \pm 1.3$ & $1.9 \pm 1.6 \mathrm{a}$ \\
\hline \multicolumn{6}{|l|}{2016} \\
\hline TC Okinawan & $4,791 \pm 517 \mathrm{a}$ & $1,719 \pm 185$ & $6,511 \pm 525$ & $0.9 \pm 0.5$ & $37.2 \pm 10.0 \mathrm{a}$ \\
\hline LA 08-21p & $3,712 \pm 435 \mathrm{ab}$ & $1,979 \pm 560$ & $5,691 \pm 813$ & $17.3 \pm 4.2$ & $5.1 \pm 0.5 b$ \\
\hline Block & 0.890 & 0.94 & 0.940 & 0.490 & 0.850 \\
\hline Treatment $(\mathrm{T})$ & 0.090 & 0.04 & 0.006 & 0.002 & 0.018 \\
\hline $\mathrm{T} \times \mathrm{Y}$ & 0.017 & 0.18 & 0.090 & 0.410 & 0.006 \\
\hline
\end{tabular}

${ }^{\mathrm{z}} \mathrm{l}$ inch $=2.54 \mathrm{~cm}, \mathrm{l} \mathrm{oz}=28.3495 \mathrm{~g}, \mathrm{l} \mathrm{kg} \cdot \mathrm{ha}^{-1}=0.8922 \mathrm{lb} /$ acre.

${ }^{\mathrm{y}}$ For cultivars, means followed by the same letter are not different at $P \leq 0.05$, as determined by Waller-Duncan k ratio test. For cultivars within a cropping season, means followed by the same letter are not different at $P<0.017$, as determined by a pairwise $t$ test of least-square means with a Bonferroni comparisons correction (Dunn, 1961). $\mathrm{DW}=$ dry weight $\mathrm{TC}=$ tissue-cultured, virus-tested.

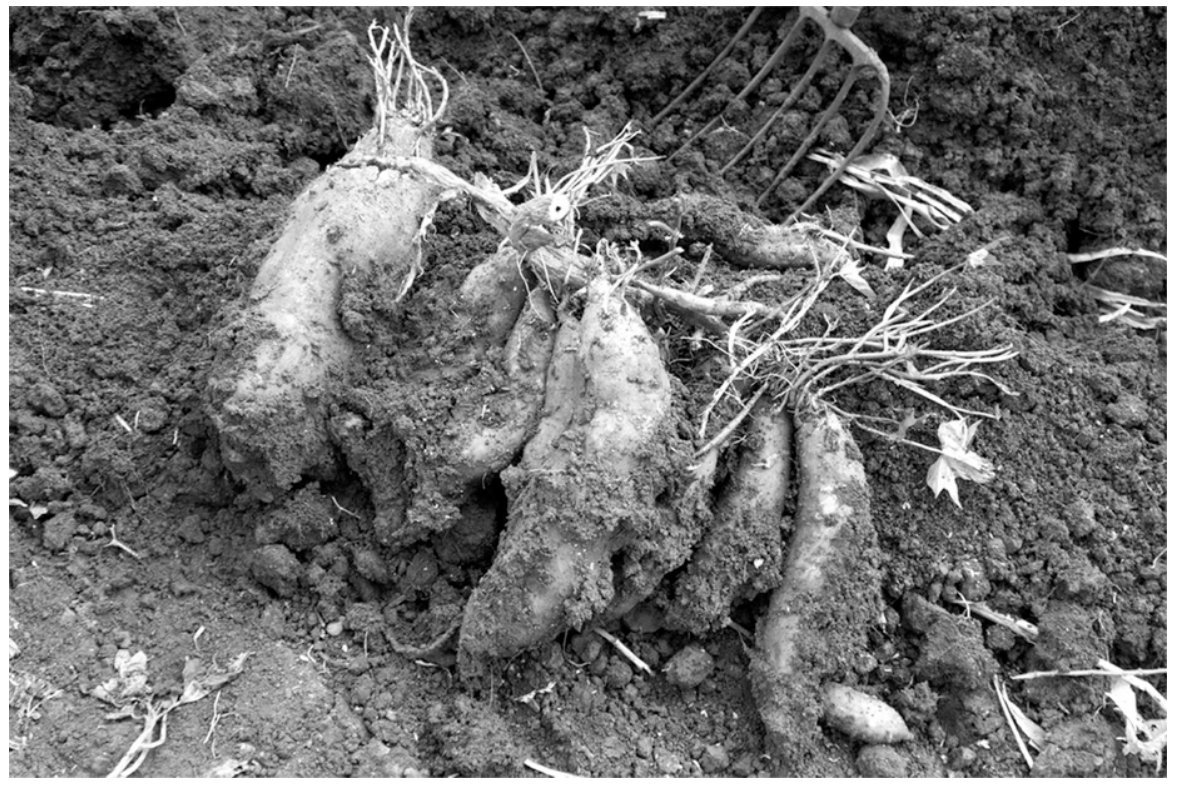

Fig. 3. Sweetpotato cultivar LA 08-21p with tight clusters of storage roots that grow near the surface of the soil.

\section{Literature cited}

Barlow, T. and L.H. Rolston. 1981. Types of host plant resistance to the sweetpotato weevil found in sweetpotato roots. J. Kans. Entomol. Soc. 54:649657.

Bryan, A.D., J.R. Schultheis, Z. PesicVanEsbroeck, and G.C. Yencho. 2003. Cultivar decline in sweetpotato: II. Impact of virus infection on yield and storage root quality in 'Beauregard' and 'Hernandez'. J. Amer. Soc. Hort. Sci. 128:856-863.

Carroll, H.W., A.G. Villordon, C.A. Clark, D.R. LaBonte, and M.W. Hoy. 2004. Studies on Beauregard sweetpotato clones naturally infected with viruses. Intl. J. Pest Mgt. 50:101-106.

Clark, C.A., J.A. Davis, J.A. Abad, W.J. Cuellar, S. Fuentes, J.F. Kreuze, R.W. Gibson, S.B. Mukasa, A.K. Tugume, F.D. Tairo, and J.P.T. Valknen. 2012. Sweetpotato viruses: 15 Years of progress on 
understanding and managing complex diseases. Plant Dis. 96:168-185.

Clark, C.A., D.M. Ferrin, T.P. Smith, and G.J. Holmes. 2013. Compendium of sweetpotato diseases, pests, and disorders. 2nd ed. APS Press, St. Paul, MN.

Clark, C.A. and M.W. Hoy. 2006. Effects of common viruses on yield and quality of Beauregard sweetpotato in Louisiana. Plant Dis. 90:83-88.

Clark, C.A., R.A. Valverde, S. Fuentes, L.F. Salazar, and J.W. Moyer. 2002. Research for improved management of sweetpotato pests and diseases: Cultivar decline. Acta Hort. 583:103-112.

Dunn, O.J. 1961. Multiple comparisons among means. J. Amer. Statistical Assn. $56: 52-64$.

Follett, P.A. 2006. Irradiation as a methyl bromide alternative for postharvest control of Omphisa anastomosalis (Lepidoptera: Pyralidae) and Euscepes postfasciatus and Cylas formicarius elegantulus (Coleoptera: Curculionidae) in sweet potatoes. J. Econ. Ent. 99:32-37.

Franke, A.A., L.J. Custer, C. Arakaki, and S.P. Murphy. 2004. Vitamin C and flavonoid levels of fruits and vegetables consumed in Hawaii. J. Food Compos. Anal. 17:1-35.

Gu, Y.H., X. Tao, X.J. Lai, H.Y. Wang, and Y.Z. Zhang. 2014. Exploring the polyadenylated RNA virome of sweet potato through high-throughput sequencing. PLoS One 9(6):e98884

Ha, C., S. Coombs, P.A. Revill, R.M. Harding, M. Vu, and J.L. Dale. 2008. Design and application of two novel degenerate primer pairs for the detection and complete genomic characterization of potyviruses. Arch. Virol. 153:25-36.

Hahn, S.K. and K. Leuschner. 1982. Breeding sweet potato for weevil resistance, p. 331-336. In: R.L. Villareal and T.D. Griggs (eds.). Sweet potato: Proc. First Intl. Symp. AVRDC Publ. No. 82-172.

Hawaii Department of Agriculture. 2013. Statistics of Hawaii agriculture 2011. Hawaii Department of Agriculture, Honolulu.

Hawaii Department of Agriculture. 1974. Sub-section 5.40. Standards for Hawaii- grown sweet potatoes. Hawaii Department of Agriculture Division of Marketing and Consumer Services, Honolulu, $\mathrm{HI}$

Heu, A., D. Tsuda, S. Fukuda, C. Young, and M. Lee. 2014. New pest Advisory. 23 May $2017<\mathrm{http}: / /$ hdoa.hawaii.gov/pi/ files /2013/01/NPA-Blosyrus-MASTER. pdf $>$.

Hue, N.V., R. Uchida, and M.C. Ho. 2000. Sampling and analysis of soils and plant tissues: How to take representative samples, how samples are tested, p. 2330. In: J.A. Silva and R. Uchida (eds.). Plant nutrient management in Hawaii's soils, approaches for tropical and subtropical agriculture. College of Tropical Agriculture and Human Resources, University of Hawaii at Manoa. 25 May 2017. <http://www.ctahr.hawaii.edu/oc/ freepubs/pdf/pnm2.pdf>

Jackson, D.M. and H.F. Harrison, Jr. 2013. Insect resistance in traditional and heirloom sweetpotato varieties. J. Econ. Entomol. 106:1456-1462.

Kreuze, J.F., A. Perez, M. Untiveros, D. Quispe, S. Fuentes, I. Barker, and R. Simon. 2009. Complete viral genome sequence and discovery of novel viruses by deep sequencing of small RNAs: A generic method for diagnosis, discovery and sequencing of viruses. Virology 388:1-7.

LaBonte, D.R., A.Q. Villordon, C.A. Clark, P.W. Wilson, and C.S. Stoddard. 2008. 'Murasaki-29' sweetpotato. HortScience 43:1895-1896.

Li, R., R. Mock, Q. Huang, J. Abad, J. Hartung, and G. Kinard. 2008. A reliable and inexpensive method of nucleic acid extraction for the PCR-based detection of diverse plant pathogens. J. Virol. Methods 154:48-55.

Li, R., S. Salih, and S. Hurtt. 2004. Detection of geminiviruses in sweetpotato by polymerase chain reaction. Plant Dis. 88:1347-1351.

Li, F., R. Zuo, J. Abad, D. Xu, G. Bao, and R. Li. 2012. Simultaneous detection and differentiation of four closely related sweet potato viruses by a multiplex onestep RT-PCR. J. Virol. Methods 186:161166.

Ling, K.S., D.M. Jackson, H. Harrison, A.M. Simmons, and Z. Pesic-VanEsbroeck. 2010. Field evaluation of yield effects on the U.S.A. heirloom sweetpotato cultivars infected by sweet potato leaf curl virus. Crop Prot. 29:757-765.

Mao, L., R.N. Story, A.M. Hammond, and D.R. Labonte. 2001. Effect of sweetpotato genotype, storage time and production site on feeding and oviposition behavior of the sweetpotato weevil, Cylas formicarius (Coleoptera: Apoinidae). Fla. Entomol. 84:259-264.

Melzer, M. 2014. CAPS survey accomplishment report. University of Hawaii, Honolulu.

Nottingham, S.F. and S.J. Kays. 2002. Sweetpotato weevil control. Acta Hort. 583:155-161.

Stathers, T.E., D. Rees, S. Kabi, L. Mbilinyi, N. Smit, H. Kiozya, S. Jeremiah, A. Nyango, and D. Jeffries. 2003. Sweetpotato infestation by Clyas spp. in east Africa: I. Cultivar differences in field infestation and the role of plant factors. Intl. J. Pest Mgt. 49:131-140.

Stevenson, P., H. Muyinza, D.R. Hall, E.A. Porter, D.I. Farman, H. Talwana, and R.O.M. Mwanga. 2009. Chemical basis for resistance in sweetpotato Ipomoea batatas to the sweetpotato weevil Cylas puncticollis. Pure Appl. Chem. 81:141151.

Teow, C.C., V.-D. Truon, R.F. McFeeters, R.L. Thompson, K.V. Pecota, and G.C. Yencho. 2007. Antioxidant activities, phenolic and beta-carotene contents of sweet potato genotypes with varying flesh colours. Food Chem. 103:829-838.

Villordon, A.Q. and D.R. LaBonte. 1995. Variation in randomly amplified DNA markers and storage root yield in 'Jewel' sweetpotato clones. J. Amer. Soc. Hort. Sci. 120:734-740.

Wang, S., S. Nie, and F. Zhu. 2016. Chemical constituents and health effects of sweet potato. Food Res. Intl. 89:90116.

Yost, R.S. and R. Uchida. 2000. Interpreting soil nutrient analysis data: Definition of "low," "sufficient," and "high" nutrient levels, p. 87-89. In: J.A. Silva and R. Uchida (eds.) Plant nutrient management in Hawaii's soils, approaches for tropical and subtropical agriculture. 25 May 2017. <http://www.ctahr.hawaii. edu/oc/freepubs/pdf/pnm7.pdf>. 